\title{
ПІДГОТОВКА МАЙБУТНІХ УЧИТЕЛІВ ПОЧАТКОВИХ КЛАСІВ ДО ЕКОЛОГІЧНОГО ВИХОВАННЯ УЧНІВ
}

\author{
Партола В. В. \\ кандидат педагогічних наук, \\ доиент кафедри теорії і методики викладання природничо-математичних дисциплін \\ у дошкільній, початковій $і$ спечіальній освіті \\ Харківський національний педагогічний університет імені Г. С. Сковороди \\ вул. Валентинівська, 2, Харків, Украӥна \\ orcid.org/0000-0002-2575-9692 \\ partolav@gmail.com
}

\section{Смолянюк Н. М.}

кандидат педагогічних наук,

доиент кафедри теорії і методики викладання природничо-математичних дисциплін

у дошкільній, початковій і спеціальній освіті

Харківський національний педагогічний університет імені Г. С. Сковороди

вул. Валентинівська, 2, Харків, Украӥна

orcid.org/0000-0003-3524-581X

smolnat02@gmail.com

\section{Старікова Л. П.}

кандидат педагогічних наук,

дочент кафедри теорії і методики викладання природничо-математичних дисциплін у дошкільній, початковій і спеціальній освіті

Харківський національний педагогічний університет імені Г. С. Сковороди

вул. Валентинівська, 2, Харків, Україна

orcid.org/0000-0001-9106-2239

luda.p.starik@gmail.com

Ключові слова: екологічне виховання, підготовка, навчальні програми, майбутні вчителі, початкові класи.
У статті розкрито питання підготовки майбутніх учителів початкових класів до екологічного виховання учнів початкових класів 3 досвіду роботи кафедри теорії і методики викладання природничо-математичних дисциплін у дошкільній, початковій та спеціальній освіті Харківського національного педагогічного університету ім. Г.С. Сковороди. Визначено поняття «підготовка майбутніх учителів початкових класів до екологічного виховання учнів», обгрунтовано модель підготовки майбутнього вчителя до екологічного виховання школярів в умовах закладу вищої освіти педагогічного профілю. Встановлено, що поняття «підготовка майбутніх учителів до екологічного виховання молодших школярів» розкривається через систему, компонентами якої $\epsilon$ екологічні знання, професійно значущі особистісні якості майбутнього педагога, володіння сучасними технологіями навчання та методами екологічного виховання молодших школярів. Характеризується модель підготовки майбутнього вчителя до екологічного виховання в умовах ЗВО педагогічного профілю. 3' ясовано, що під час навчання у ЗВО педагогічного профілю, зокрема на факультеті початкового навчання, питання екології й охорони навколишнього середовища $\epsilon$ складовою частиною таких навчальних дисциплін природничо-математичного циклу, як: основи природознавства (основи 
ботаніки, зоології і землезнавства), суспільствознавство та основи екології. У реалізації змісту екологічного виховання особливої ваги набуває предмет «Методика викладання освітньої галузі «Природознавство». Важливу роль в екологічному вихованні студентів відіграють також предмети психолого-педагогічного циклу, педагогічні та польові практики. Роз'яснено, що для активізації наукової діяльності студентів у галузі питань екологічного виховання молодших школярів на кафедрі теорії і методики викладання природничоматематичних дисциплін у дошкільній, початковій та спеціальній освіті здійснюється робота 3 підготовки наукових робіт студентів у зазначеній сфері діяльності, - це підготовка під керівництвом викладача кафедри доповіді для виступу на студентській науково-практичній конференції з подальшою публікацією тез доповіді у науковій збірці.

\title{
FUTURE PRIMARY SCHOOL TEACHERS' TRAINING FOR ENVIRONMENTAL EDUCATION OF PRIMARY SCHOOL STUDENTS
}

\author{
Partola V. V. \\ Candidate of Pedagogical Sciences, \\ Associate Professor at the Department of Theory and Methods of Teaching Natural \\ and Mathematical Disciplines in Preschool, Primary and Special Education \\ H. S. Skovoroda Kharkiv National Pedagogical University \\ Valentynivska str., 2, Kharkiv, Ukraine \\ orcid.org/0000-0002-2575-9692 \\ partolav@gmail.com \\ Smolyanyuk N. M. \\ Candidate of Pedagogical Sciences, \\ Associate Professor at the Department of Theory and Methods of Teaching Natural \\ and Mathematical Disciplines in Preschool, Primary and Special Education \\ H. S. Skovoroda Kharkiv National Pedagogical University \\ Valentynivska str., 2, Kharkiv, Ukraine \\ orcid.org/0000-0003-3524-581X \\ smolnat02@gmail.com \\ Starikova L. P. \\ Candidate of Pedagogical Sciences, \\ Associate Professor at the Department of Theory and Methods of Teaching Natural \\ and Mathematical Disciplines in Preschool, Primary and Special Education \\ H. S. Skovoroda Kharkiv National Pedagogical University \\ Valentynivska str., 2, Kharkiv, Ukraine \\ orcid.org/0000-0001-9106-2239 \\ luda.p.starik@gmail.com
}

Key words: environmental education, training, educational programs, future teachers, primary classes.
The article reveals the issue of future primary school teachers' training for environmental education of primary school students from the experience of the Department of Theory and Methods of Teaching Natural and Mathematical Disciplines in Preschool, Primary and Special Education of H.S. Skovoroda Kharkiv National Pedagogical University. The concept of "training of future primary school teachers for ecological education of students" is defined, the model of preparation of future teacher for ecological education of schoolchildren in the conditions of higher education institution of pedagogical profile is substantiated. It is established that the concept "training of future teachers for environmental education of primary school children" is revealed through a system with such 
components as environmental knowledge, professionally significant personal qualities of future teacher, modern teaching technologies and methods of environmental education of primary school students. The model of preparation of the future teacher for ecological education in the conditions of higher educational establishment of pedagogical profile is characterized. It was found out that during education in higher educational institution of pedagogical profile, in particular, at faculty of primary education the questions of ecology and environmental protection are an integral part of educational disciplines of natural and mathematical cycle as: Fundamentals of natural sciences (Fundamentals of botany, zoology and geology), Social sciences and fundamentals and Fundamentals of ecology. In the implementation of the content of environmental education special attention is paid to the subject "Methods of teaching the educational field of "Natural history". An important role in the environmental education of students is also played by the subjects of psychological and pedagogical cycle, pedagogical and field practices. It is explained that in order to intensify the scientific activity of students in the field of environmental education of primary school students at the Department of Theory and Methods of Teaching Natural and Mathematical Disciplines in Preschool, Primary and Special Education, work is carried out to training students' scientific works under the guidance of the lecturer of the department of the report for the speech at the student scientific-practical conference with the subsequent publication of the abstracts of the report in the scientific collection.

У зв'язку 3 реформуванням системи освіти України набуває особливої актуальності проблема підготовки спеціалістів екологічно грамотного молодого покоління, здатного здійснювати екоцентричний підхід у взаємодії з природою. Сучасна освіта ставить у центр освітньої діяльності виховання екологічної грамотності, культури особистості та суспільства. Зважаючи на значимість такої проблеми, починати процес виховання екологічної культури людини потрібно якомога раніше. Уже у початковій школі потрібно починати здійснювати спрямовану роботу з екологічного виховання учнів. Результативність її значною мірою залежить від професійних якостей і вмінь учителя.

У зв'язку з цим перед педагогічним вищим освітнім закладом постає завдання - підготувати майбутніх учителів початкових класів до еколого-педагогічної діяльності, в якій засвоєння знань, умінь і навичок 3 цілей освіти змінилося 6 на технологічність виховання екологічної культури учнів, формування відповідних моделей екологічного мислення і діяльності [2]. Оволодіння такою здатністю являє сутність готовності майбутніх учителів початкових класів до екологічного виховання учнів молодших класів.

Аналіз науково-педагогічної та спеціальної методичної літератури із зазначеної проблеми показав, що проблема підготовки майбутніх учителів початкових класів до екологічного виховання молодших школярів не піддавалася глибокому спеціальному дослідженню. Вона розглядалася зазвичай у широкому контексті проблеми формування професійно-педагогічної спрямованості майбутніх фахівців.

Питаннями підготовки майбутнього вчителя до професійної діяльності, зокрема екологічної, займалися такі вчені, як: І. Богданова, А. Капська, І. Кобиляцька, 3. Курлянд, Н. Сметанський, Л. Чайка та інші.
Мета статті - розкрити поняття «підготовка майбутніх учителів початкових класів до екологічного виховання учнів», обгрунтувати модель підготовки майбутнього вчителя до екологічного виховання школярів в умовах закладу вищої освіти педагогічного профілю.

Аналіз науково-педагогічної літератури показав, що поняття «підготовка майбутніх учителів до екологічного виховання молодших школярів» $€$ багатокомпонентним утворенням і включає певні складники. Насамперед це знання, що утворюють своєрідне підгрунтя екологічно спрямованої діяльності майбутнього вчителя початкових класів, а також вміння розвивати екологічну активність молодших школярів, тобто діяльнісно-практичний складник, мотиваційно-ціннісна і творча компоненти [2;6].

Екологічна освіта, на думку О. Савченко, - це отримання знань за допомогою тих спеціалізованих предметів і дисциплін, що містять у назвах термін «екологія» і скеровані на вивчення живих істот із середовищем їх існування [5].

Так, під час навчання у ЗВО педагогічного профілю, зокрема на факультеті початкового навчання, питання екології й охорони навколишнього середовища $є$ складовою частиною таких навчальних курсів, як: основи природознавства (основи ботаніки, зоології і землезнавства), суспільствознавство та основи екології. Зміст зазначених предметів сприяє розвитку знань студентів про особливості й закономірності життя на планеті, взаємозв'язки у природі, роль природи у житті суспільства, про екологічний стан на планеті та залежність його від діяльності людини тощо. Особливого значення у цьому зв'язку набуває вивчення спеціальної дисципліни «Основи екології».

Слід зазначити, що під час навчання основ екології головна увага приділяється як змісту, так і емоційності занять. У процесі бесід та дискусій 
ставиться важливе завдання сформувати у студентів розуміння, що вирішення глобальних екологічних проблем людства, які у наш час набувають катастрофічного характеру, залежить перш за все від ставлення людини до навколишнього світу, системи іiі екологічних цінностей, рівня екологічної свідомості [6].

Дисципліни природничо-математичного циклу створюють умови для розвитку вмінь оцінювати стан природних об'єктів і явищ, позитивні і негативні наслідки діяльності людини у природному і соціальному довкіллі, дають можливість здійснювати аналіз питань про процеси, що відбуваються у навколишньому середовищі, необхідність дбайливого ставлення до нього, раціонального користування багатствами природи [1].

Значну роль в екологічному вихованні студентів відіграють польові практики. Вони сприяють розвитку еколого-орієнтованих цінностей, спілкуванню 3 природою і грамотному поводженню у природному середовищі; розвитку естетичних $\mathrm{i}$ моральних стосунків з навколишнім середовищем.

Слід також звернути увагу на важливу роль дисциплін психолого-педагогічного циклу у підготовці майбутнього вчителя початкових класів до екологічного виховання школярів. Так, частково ці питання висвітлюються у курсі історії педагогіки, народної педагогіки, дидактики тощо.

У курсі психолого-педагогічних дисциплін розглядаються вікові особливості учнів, особливості сприйняття ними навколишнього світу, ставлення до об'єктів та явищ природи; студенти ознайомлюються зі змістом, завданнями виховання загалом та екологічного виховання зокрема, формами та методами організації навчально-виховної роботи у школі.

Важливими є види практичної професійної підготовки під час проведення педагогічних практик, у процесі яких студенти формують уміння самостійно організовувати та проводити різноманітні види, форми роботи з екологічного виховання учнів.

Установлено також, що підготовка майбутніх учителів початкових класів до екологічного виховання учнів, крім володіння екологічними знаннями на достатньому професійному рівні, включає у себе усвідомлення студентами необхідності й значення роботи з екологічного виховання молодших учнів, знання психолого-педагогічних механізмів екологічно вихованих, володіння методами та технологіями екологічного виховання учнів, уміння проаналізувати отримані результати, провести їх корекцію [2; 4].

Залежно від того, яким буде вчитель, як він буде користуватись своїми теоретичними та практичними знаннями стосовно екологічного виховання, залежить і рівень вихованості молодого покоління, сформованість екологічної культури, загальний рівень вихованості та, врешті-решт, вирішення сучасних екологічних питань.

Теорія та методика професійної підготовки майбутнього вчителя початкових класів до екологічного виховання учнів особливу увагу приділяє саме методам та технологіям, за допомогою яких реалізується зміст екологічного виховання. Ці методи та технології складаються із сукупності конкретних методів, прийомів та засобів, а також організації екологічної діяльності учнів, у яких реалізуються цілі, завдання та принципи екологічного виховання.

У цьому зв'язку особливої уваги набуває предмет «Методики викладання освітньої галузі «Природознавство». Так, на заняттях «Методики викладання освітньої галузі «Природознавство», спецкурсів «Формування природознавчої компетентності» та «Народознавство» використовуються рольові і ділові ігри, проводяться фрагменти уроків, диспути, тренінги 3 екологічною спрямованістю, розробляються сценарії проведення тематичних вечорів, що загалом сприяє кращій обізнаності і підготовці майбутніх учителів до організації навчально-виховної роботи 3 молодшими школярами у майбутній професійній діяльності.

Підготовка студентів здійснюється в аудиторних умовах на лекційних, семінарських, практичних заняттях вищевказаних курсів. Водночас досягненню завдань підготовки студентів до екологічного виховання учнів сприяє організація позааудиторної діяльності студентів: організація навчально-виховних екскурсій, перегляд відеофільмів про природу, залучення до організації та проведення святкових вечорів, конкурсів стендів та плакатів, фотовиставок на природничо-екологічну тематику, залучення до участі у природоохоронних акціях тощо.

Так, для активізації наукової діяльності студентів у галузі питань екологічного виховання молодших школярів на кафедрі теорії і методики викладання природничо-математичних дисциплін у дошкільній, початковій та спеціальній освіті здійснюється робота 3 підготовки наукових робіт студентів у зазначеній сфері діяльності. Молоді вчені проводять дослідження в таких напрямах, як: розвиток пізнавального інтересу та активізація пізнавально-навчальної діяльності молодших школярів під час вивчення живої природи; екологічне виховання засобами народної педагогіки; формування екологічної культури як сучасної парадигми розвитку соціокультурного й навчально-виховного процесу; екологічна етика як антропологічний орієнтир для сучасної людини тощо.

Одна 3 організаційних форм роботи зі студентами - це підготовка під керівництвом викладача 
кафедри доповіді для виступу на студентській науково-практичній конференції 3 подальшою публікацією тез доповіді у науковій збірці.

Для формування у студентів екологічної культури, екологічної моральності і екологічної етики, готовності до майбутньої професійної діяльності в умовах освітнього навчального закладу використовуються такі форми роботи, як: участь студентів у підготовці та розробці екологічних заходів для загальноосвітніх шкіл, що сприяє розвитку творчості і самостійності в просвітницькій діяльності майбутніх педагогів; створення презентацій та підбір відеофільмів, відеосюжетів про біорізноманітність і екологічні проблеми регіону; проведення круглих столів, дискусій з обговоренням актуальних екологічних проблем, питань екологічної освіти і виховання школярів; участь студентів в екологічних заходах загальноуніверситетського рівня та на факультеті початкового навчання; проведення виставок та конкурсів екологічних проєктів студентів; організація студентських екологічних акцій з охорони природи рідного краю, важливим аспектом яких $€$ агітаційний характер та ін.

Професійна підготовка майбутнього вчителя початкових класів до екологічного виховання учнів здійснюється і у процесі навчання на другому (магістерському) рівні освіти. Студентам пропонуються для вивчення вибіркові дисципліни: «Інтерактивні технології навчання і виховання молодших школярів», «Технологіï stemосвіти», «Формування природничо-математичної компетентності майбутніх першокласників», програми яких передбачають вивчення тем екологічної спрямованості і розробку фрагментів уроків різних типів, проведення позаурочної роботи та підготовку заходів позакласної роботи екологічного змісту.

Наприклад, предметом вивчення навчальної дисципліни «Інтерактивні технології навчання i виховання молодших школярів» $\epsilon$ оволодіння знаннями про інтерактивні технології навчання природознавчої галузі, у тому числі обізнаність технологічності навчання основ екологічних знань та умінь застосування (реалізації) їх в освітньому процесі у закладах загальної середньої освіти (початкової школи); розвиток творчої активності студентів, формування вміння проєктувати, організовувати, проводити екологічні заходи у початковій школі. Мета вивчення навчальної дисципліни - сформувати цілісну систему знань у майбутніх педагогів про використання інтерактивних технологій природничого і в тому числі екологічного навчання; ознайомити на практиці 3 різними видами інтерактивних технологій екологічного навчання та методикою організації роботи з їх застосуванням у сучасній початковій школі; формувати у майбутніх учителів початкових класів стійке прагнення до розвитку, самовдосконалення, самопізнання 3 метою вироблення індивідуального стилю в роботі екологічного виховання молодших школярів.

Метою навчальної дисципліни «Технології stem-освіти» $\epsilon$ підготовка майбутніх учителів початкових класів до реалізації основних положень stem-освіти, тобто такого підходу до освітнього процесу, відповідно до якого основою набуття знань стає проста та доступна візуалізація наукових природничих, екологічних явищ, що дає змогу легко охопити і здобути знання на основі практики та глибокого розуміння процесів. Stem-освіта не лише спрямовує увагу на природничо-науковий компонент навчання та інноваційні технології, але й активно розвиває творчий складник особистості та критичне мислення, ставлення до довкілля. Розвиток особистості учня початкової школи, його екологічної культури можливий із застосуванням stem-підходу 3 використанням stem-засобів. Такі засоби вчать досліджувати та опановувати закони природи, взаємодію між об'єктами неживої і живої природи, а також дають уявлення про те, як функціонує навколишній природний світ. Завдання вивчення дисципліни - формування у здобувачів компетентностей щодо використання ефективних освітніх практик для екологічного stem-навчання учнів молодшого шкільного віку; розробка та проведення у початковій школі stem-уроків, у тому числі таких, що несуть екологічне навантаження; організація освітнього процесу на екологічних stem-уроках з урахуванням особливостей засвоєння інформації дітьми Z-покоління. Результатами такого навчання стає опанування ефективних освітніх практик stem-освіти учнів початкової школи; готовність до роботи з дітьми Z-покоління; здатність до розробки stem-уроків із використанням кейсів, лайфаків, нестандартних методичних прийомів (е-навчання, vr-візуалізація навчання тощо), які впливають на формування цілісної картини світу школярів, їхню екологічну культуру, ціннісне ставлення до природного довкілля, що перебуває повсякденно під впливом продуктів діяльності людства.

Предметом вивчення вибіркової дисципліни «Формування природничої компетентності майбутніх першокласників» $\epsilon$ опанування теоретичних і методичних засад формування природничої компетентності майбутніх першокласників, становлення й удосконалення професійної компетентності майбутнього вчителя початкових класів, спрямованої на реалізацію принципу наступності в освітньому процесі, а саме підготовку дітей до школи. Відомо, що перше знайомство з картиною світу у дитини відбувається через спілкування 
3 довкіллям (природним, предметним, соціальним). Тому ця дисципліна вирішує завдання: формувати готовність застосовувати отримані теоретичні й методичні знання для реалізації цілісного підходу до розвитку природничої компетентності дітей у процесі підготовки до школи; формувати позитивне ставлення майбутніх учителів початкової школи до організації навчальної діяльності, спрямованої на формування природничої компетентності майбутніх першокласників, на виховання екологічної культури, формування самостійності мислення, дій поведінки у природі; розвивати прагнення магістрантів до самонавчання та самовдосконалення, постійного професійного розвитку, створення розвивального навчального середовища, спрямованого на екологічне виховання дитини.

Таким чином, у результаті навчально-методичної і практичної підготовки майбутніх учителів початкових класів на факультеті початкової освіти у студентів формується готовність до здійснення екологічного виховання учнів. У цілому загальна модель вузівської підготовки учителя до екологічного виховання школярів в умовах $3 В О$ педагогічного профілю передбачає формування екологічного мислення, заснованого на знаннях, уміннях і навичках про об'єкти, процеси та явища довкілля, науковому обгрунтуванні, критичному осмисленні й творчому застосуванні певних концепцій, форм і методів пізнання, керування і конструювання педагогічної теорії і практики з метою вирішення професійно-педагогічних питань, осмислення власного педагогічного досвіду, особистісно значущих чинників власного саморозвитку і розвитку особистісних структур і свідомості своїх учнів.

Інтелектуально-знаннєві та творчі складники цієї культури утворюють екологічну свідомість, мотиваційно-ціннісні і діяльнісно-практичні компоненти утворюють методичну компетентність. Екологічна свідомість і методична компетентність формують стиль мислення (екологічний), тобто виконують, формують світогляду функцію [3].

Отже, екологічна культура учня залежить від такої, що сформована у майбутнього педагога у навчальному педагогічному закладі і є складною багаторівневою структурою. Вона може бути охарактеризована загальними компонентами - екологічною свідомістю, компетентністю, індивідуально-знаннєвими i ціннісними компонентами. Водночас може бути охарактеризована єдністю ціннісно-мотиваційної, інтелектуально-когнітивної, діяльнісно-практичної й творчої сфер діяльності вчителя, що забезпечують новизну і визначають стиль професійного мислення, активізують неповторний професійний досвід педагога. Для майбутнього вчителя початкових класів кожен 3 компонентів включає ті якості й риси, що ціннісно характеризують його як представника педагогічної і природничо-наукової культур.

Проаналізований нами перелік навчальних дисциплін i напрямів формування екологічної культури майбутнього вчителя початкової школи дає змогу стверджувати, що загалом на факультеті діє певна модель підготовки майбутнього учителя до екологічного виховання школярів, формування у студентів складного особистісного утворення у процесі їх професійної підготовки у вищій педагогічній школі для екологічного виховання молодших школярів.

Висновки. Підготовка майбутніх учителів початкових класів до екологічного виховання учнів - це цільний навчально-виховний процес, спрямований на розвиток особистісних якостей майбутнього вчителя, пов'язаних зі ставленням до навколишнього середовища, природоохоронної діяльності та роботи вчителя 3 питань екологічного виховання, на формування екологічних знань, умінь та навичок, системи відповідних професійно-педагогічних знань, умінь і навичок, які б забезпечували якість процесу екологічного виховання молодших школярів.

\section{ЛІТЕРАТУРА}

1. Екологічна освіта та виховання молодших школярів : методичні матеріали для студентів денної форми навчання за напрямом підготовки «Початкова освіта» / упоряд. О.П. Грошовенко. Вінниця, 2010. 82 c.

2. Ільман В. Діяльні аспекти вдосконалення професійної підготовки вчителя початкової школи: сучасні тенденції. Рідна школа. 2011. № 1-2. С. 30-37.

3. Лаврентьєва О.О. Розвиток методологічної культури майбутнього вчителя природничих дисциплін у процесі професійної підготовки: теоретико-методичний аспект : монографія. Київ, 2014. 456 с.

4. Методика навчання природознавства : робочий зошит з методичними матеріалами : навчально-методичний посібник для студентів денної форми навчання за напрямом підготовки «Початкова освіта» / уклад. О.П. Грошовенко, Л.А. Присяжнюк. Вінницький держ. пед. ун-т ім. М. Коцюбинського. Вінниця, 2011. 204 с.

5. Савченко О.Я. Дидактика початкової школи. Київ, 1999. 324 с.

6. Тарасенко Г.С. Взаємозв'язок естетичної та екологічної підготовки вчителя в системі професійної освіти : монографія. Черкаси, 2006. 308 с. 


\section{REFERENCES}

1. Ghroshovenko, O.P. (ed.) (2011). Ekologhichna osvita ta vykhovannja molodshykh shkoljariv [Ecological education and upbringing of junior schoolchildren]. Vinnycja: VDPU im. M. Kocjubynsjkogho.

2. Iljman, V. (2011). Dijaljni aspekty vdoskonalennja profesijnoji pidghotovky vchytelja pochatkovoji shkoly: suchasni tendenciji [Active aspects of improving the professional training of primary school teachers: current trends]. Native school. Vol. 1-2. Pp. 30-37.

3. Lavrentjjeva, O.O. (2014). Rozvytok metodologhichnoji kuljtury majbutnjogho vchytelja pryrodnychykh dyscyplin u procesi profesijnoji pidghotovky: teoretyko-metodychnyj aspekt [Development of methodological culture of the future teacher of natural sciences in the process of professional training: theoretical and methodological aspect]. Monoghrafija [Monograph]. Kiev.

4. Ghroshovenko, O.P., Prysjazhnjuk, L.A. (ed.) (2014). Metodyka navchannja pryrodoznavstva [Methods of teaching science]. Vinnycja: VDPU im. M. Kocjubynsjkogho.

5. Savchenko, O.Ya. (1999). Dydaktyka pochatkovoji shkoly [Didactics of primary school]. Kyiv.

6. Tarasenko, Gh.S. (2006). Vzajemozv'jazok estetychnoji ta ekologhichnoji pidghotovky vchytelja v systemi profesijnoji osvity [Relationship between aesthetic and environmental teacher training in the vocational education system] : Monoghrafija [Monograph]. Cherkasy. 